\title{
個人の自転車利用履歴が違法駐輪に及ぼす影響に関する研究* A Study on the Effect of Past Experience of Bicycle Usage on Illegal Parking*
}

山下晴美**、古池弘隆***、森本章倫****

By Harumi YAMASHITA, Hirotaka KOIKE and Akinori MORIMOTO

\section{1. はじめに}

\section{(1) 背景}

わが国における自転車交通は、環境負荷の少ない 都市交通を実現していくための手段であり、国民に 最も身近な交通手段として普及している。1997 年に 行われた「地球温暖化防止京都会議」においても、 自転車の必要性が認識されており、今後自転車利用 がより促進されていくことが予想される。その一方 で、わが国における従来の都市交通政策では、自転 車の位置付けが不十分であったために、これらを取 り巻く社会問題は多い。特に駅や商店街における自 転車の放置は深刻化している。これら放置自転車問 題に対し、わが国では 1980 年に「自転車の安全利用 の促進及び自転車駐輪場の整備に関する法律」が制 定され、施行直後の 1981 年の 98.8 万台をピークに 放置自転車台数は年々減少しており、1990 年には 56.0 万台まで減少している。しかし、いまだに放置 自転車は数多く見られるのが現状である。

違法駐輪問題に対して全国で施設整備や法律的な 取り組みが行われているが、この対策には限界があ ると考えられる。例えば、自転車駐輪場は必ずしも 駅近くに設置することができるとは限らない。そこ で今後の取り組みの一つとして、個人が自転車を放 置しないという意識を持たせる事も重要であると考 えられる。

\section{(2) 既存研究}

放置自転車問題の解決における難しさの一つに、 放置した人がそれほど真剣に社会問題として認識し ないことがあげられる。そのため、問題の解決には、 個人の「自転車を放置しないという意識の形成が 重要であると考えられる。そこで従来の自転車のマ

\footnotetext{
${ }^{*}$ Key words: 違法駐輪 自転車利用履歴

**学生員 宇都宮大学大学院工学研究科建設学専攻

干321-8585 杤木県宇都宮市陽東 7-1-2 TEL/ FAX:028-689-6224

*** フェロー Ph.D 宇都宮大学工学部

$* * * *$ 正会員 工博 宇都宮大学工学部
}

ナーに関する研究を見ると、矢野ら ${ }^{1)}$ は自転車のマ ナーを身に付けることが将来の自動車ドライバーの ための教育になると位置付け、富原ら ${ }^{2)}$ はアンケー 卜調査により高校生は交通ルールを知りながらも守 っていないという現状を指摘している。また放置自 転車問題に対する従来の研究についてまとめると、 安部ら ${ }^{3)}$ は放置自転車の実態と駐輪意識について調 查し、利用料金や目的施設までの距離に関してサー ビス水準の高い駐輪場を求めていることを把握して いる。さらに内田ら ${ }^{4)}$ は駐輪場選択行動をより良く 表現できる非集計モデルの構築を検討し、坂口ら ${ }^{5)}$ は条例と地域的取り組みの可能性について検討し、 効果があることを示している。また藤井ら ${ }^{6)}$ は社会 的ジレンマ状況の一つの典型例として路上放置自転 車問題を取り上げ、心理的方略である説得的コミュ ニケーション（社会心理学において行動や意識の変 化を期待したコミュニケーションのこと）を用いる ことで 3 割の路上放置自転車問題を抑制する結果を 得ている。これは現時点での自転車利用者の意識の 改革である。

\section{(3) 研究の位置付け}

路上放置自転車問題は、私達に身近な社会的ジレ ンマ（個人の合理的な選択・行動が社会全体から見 ると望ましくない結果をもたらしている社会状況） といえる。この社会的ジレンマを解消するために行 動変容（路上駐輪しない行動をおこす）を促すには 社会心理学においていくつかの段階を踏む必要があ ると考えられている(図 1参照)。一般に、まず “〜

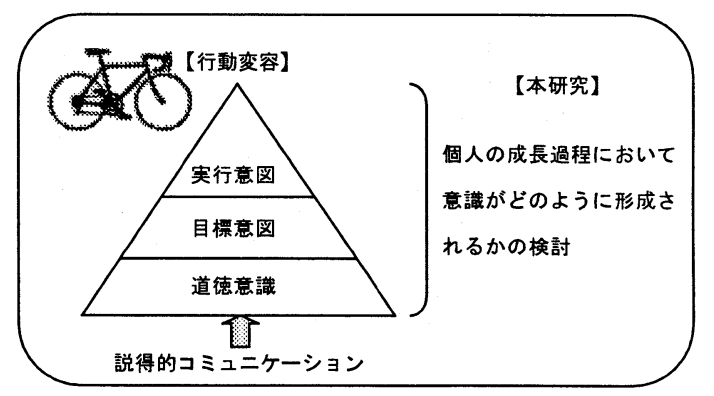

図 1. 行動変容のプロセス 
すべき”という意識は道徳意識の形成である。この 道徳意識を活性化することが「放置自転車をやめよ う」と考える目標意図 (“〜しよう”とする抽象的な 意図）を強めている。そしてこの目標意図により実 行意図（行動を実行しようという形の具体性を伴う 意図）が活性化された場合に行動変容は生じる。既 存研究では、この過程を説得的コミュニケーション によって行われていた。本研究においては、個人の 成長過程において違法駐輪行為抑制の意識がどのよ うな経験・刺激により形成されるか、アンケート調 查を用いて検討を行う。これにより今後交通安全教 室等の教育と合わせて、効果的なソフト施策の提言 を行うことを目的とする。

\section{2. 違法駐輪に対する意識調査}

\section{（1）違法駐輪に対する意識の分類}

違法駐輪する人・しない人の中でもその行動に至 るには個々に意識が異なると考えられる。そこで本 研究ではこれらの違法駐輪における意識を表 1 に示 すよう 4 つに分類 (以下意識分類と記す) する。意 識分類別に違法駐輪に対する意識をより明確にした 上で、これらの意識がどのように形成されるか検討 する。分類方法はアンケートを用いて、図 2 に示す 手順で行う。

表 1. 各意識分類の位置付け

\begin{tabular}{|c|c|}
\hline & 行動と認識の連い \\
\hline $\begin{array}{l}\text { 䢖法駐輪 } \\
\text { するA 類 }\end{array}$ & $\begin{array}{l}\text { 自転車放置する事を悪い事と認識してい } \\
\text { ない人 }\end{array}$ \\
\hline $\begin{array}{l}\text { 倳法駐輪 } \\
\text { するB 類 }\end{array}$ & $\begin{array}{l}\text { 自転車放置する事を悪い事と認識してい } \\
\text { るが放置する人 }\end{array}$ \\
\hline $\begin{array}{l}\text { 違法駐輪 } \\
\text { しないA類 }\end{array}$ & 罰則があるから自転車放置しない人 \\
\hline $\begin{array}{l}\text { 違法駐輪 } \\
\text { しないB類 }\end{array}$ & マナ \\
\hline
\end{tabular}

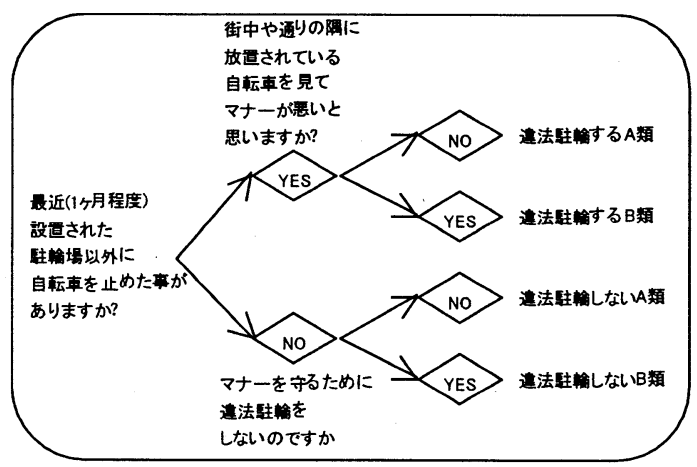

図 2. 分類方法

\section{(2) 調査内容}

放置自転車の実態と個人の違法駐輪行為に対する 意識の把握を行うために、アンケート調査を行った。 調査概要を表 2 に示す。調查対象者としては、自転 車保有率が高く自動車保有をしていない、宇都宮市 内の高校生（ 1 年生 3 年生）とした。調查は無作為 抽出により行われており、高校生全体の傾向を表し ていると言える。調査内容は属性や意識調査の他に、 個人の意識の形成を把握するために過去から現在に おける経験の有無等を含んだ内容としている。また、 個人の意識に関する項目は 5 段階評価である。 5 段 階評価は、質問に対して肯定的であれば評価值は高 くなり、否定的であれば低くなるように設定した。

また今回のアンケート調査では、違法駐輪におけ る他人への迷惑に対する意識の強さを「マナー意識」 と、社会のルールを守る実行力を「ルール遵守」と して定義する。

\section{表 2. 調查概要}

\begin{tabular}{|c|l|}
\hline & \multicolumn{1}{|c|}{ アンケート調查 } \\
\hline 対象 & 作新学院高等部 \\
\hline 日時 & 2002 年 10-11月 \\
\hline 項目 & $\begin{array}{l}\text { 属性項目 個人の過去の履歴 } \\
\text { 地域の環境 自転車利用動向 } \\
\text { 遼法駐輪に対する意識 等 }\end{array}$ \\
\hline 有効回答数 & 254 (有効回答率 $85.8 \%)$ \\
\hline
\end{tabular}

\section{3. 属性別にみた意識分類の実態把握}

\section{(1) 違法駐輪の実態把握}

アンケート対象者を 4 つの意識分類に分けたもの 図 3 に示す。これを見ると、全体の約 4 割が自転車 の違法駐輪をしていることがわかる。また、放置し ている人の半数が違法駐輪する事に対し悪い事とい う認識がなく、問題に対する認識の低さが伺える。

図中における( )の中の数字はサンプル数を示す (以降の全図も同様)。

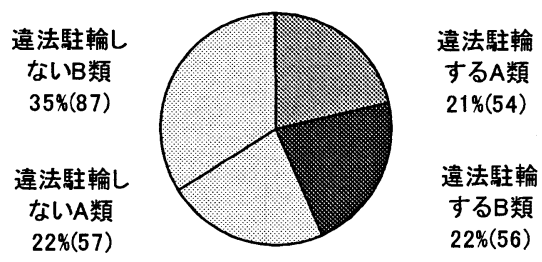

図 3. 分類方法

\section{（2）属性別にみた意識分類の経年変化}

個人属性と意識分類における因果関係を把握する ために、性別・学年別に分類の割合を調べた。ここ で「違法駐輪しない B 類」において、男子生徒・女子 
生徒共に第二学年において割合が減少するという現 象が見られた(図 4 参照)。特に男子生徒においては、 「違法駐輪する A 類」の割合が第 2 学年において増加 しており (図 5 参照)、このことより第 2 学年におい て違法駐輪に対する意識が低下していることが予想 される。

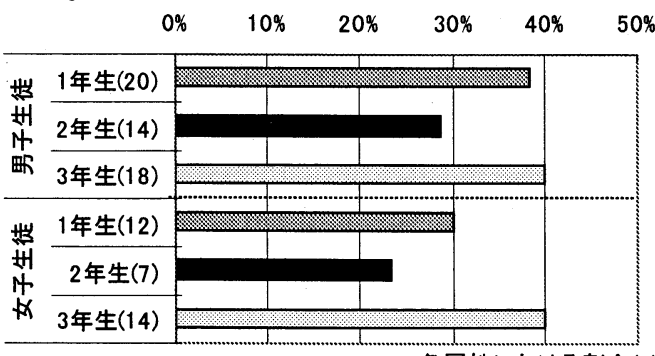

各属性における割合(\%)

図 4. 各学年における違法駐輪しないB 類の割合

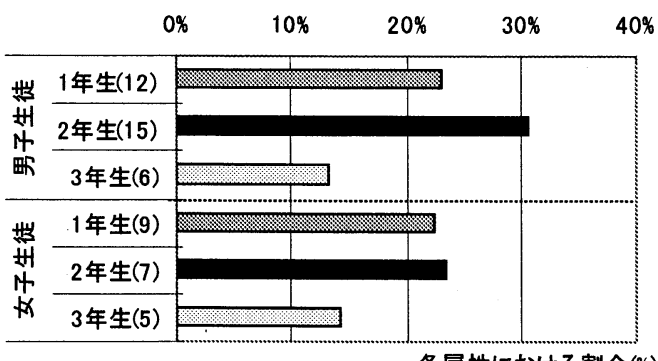

各属性における割合(\%)

図 5. 各学年における違法駐輪するA 類の割合

\section{（3）マナー意識の経年変化}

違法駐輪に対する考え方の中でも個人の意識に関 する項目について性別・学年別にみた評価值を、図 6 に示す。この結果より、「自転車を街中に放置して おくことは他人に迷惑がかかる」の項目で表される 他人への迷惑に対する意識の強さであるマナー意識 が、男子生徒・女子生徒共に第 2 学年において低下 していることが分かる。これは、第 1 学年において は中学から高校への環境変化による緊張感により、 マナー意識が保たれ、また第 3 学年においては将来 の進路を考える上で社会のモラル・常識を意識する 傾向にあるためと推測される。

以上のことを踏まえると、学生は外部の何らかの

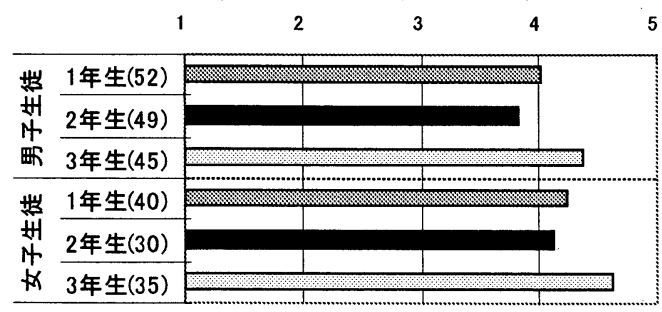

図 6. 学年別に見たマナー意識に関する平均值
影響を受けマナー意識が低下するのではないかと考 えられる。従って個人の意識を考慮した違法駐輪問 題の解決策を進めていく上で、マナー意識を低下さ せないための対策をとることも重要ではないかと考 えられる。ただし、今回のアンケートはある一時点 のデータであり、意識の経年変化を把握するために は、継続的な調査が必要である。

\section{4. 違法駐輪における意識の把握}

\section{(1) 主成分分析を用いた意識の把握}

各意識分類の違法駐輪に対する考えについて、 主成分分析を用いて特徴を明確にする。説明変数に 用いるのは、違法駐輪に対する考え方について設問 した 7 項目とする。分析の結果を表 3 に示す。第 2 主成分までの累積寄与率は $52 \%$ であ。第 1 主成分 は「違法駐輪をしてしまうのは駐輪場が無いからだ」、 「もっと駐輪場が使いやすければ違法駐輪はしな い、「駐輪場が無料ならば違法駐輪は減少する」の 項目が挙げられ、特徵として自転車駐輪場のハード 施設の充実性の要求を表す軸であると考えられる。 第 2 主成分は「自転車を街中へ放置しておくことは 他人に迷惑がかかる」といった違法駐輪に対するマ ナ一意識（この項目を「マナー意識」の軸とする。） と、「他人が違法駐輪しているとついつい自分も違 法駐輪してしまう」、「少しの時間駐輪するために駐 輪場を利用するのは面倒だ」といった社会的ルール を守る実行力（この 2 項目を「ルール遵守」の軸と する。）の弱さに負の関係が見られた。つまり、個人 のマナー意識や行動の規範となるルールの遵守が現

表 3 主成分の固有值と寄与率

\begin{tabular}{|c|c|c|}
\hline 設問項目 & $\begin{array}{l}\text { 第一主成分 } \\
\text { 固有ベクトル }\end{array}$ & $\begin{array}{c}\text { 第二主成分 } \\
\text { 固有ベクト } \\
\text { ル }\end{array}$ \\
\hline 自転車を撤去されるのは嫌だ & 0.27 & -0.28 \\
\hline $\begin{array}{l}\text { 自転車を街中に放置しておく } \\
\text { 事は他人に迷惑がかか }\end{array}$ & 0.04 & 0.67 \\
\hline $\begin{array}{l}\text { 他人が違法駐輪しているとつ } \\
\text { いつい自分も違法駐輪してし } \\
\text { まう }\end{array}$ & 0.38 & -0.40 \\
\hline $\begin{array}{l}\text { 少しの時間駐輪するために駐 } \\
\text { 輪場を利用する事は面倒た }\end{array}$ & 0.04 & -0.33 \\
\hline $\begin{array}{l}\text { もっと駐輪場が使いやすけれ } \\
\text { ば違法駐輪はしない }\end{array}$ & 0.45 & 0.34 \\
\hline $\begin{array}{l}\text { 違法駐輪をしてしまうのは駐 } \\
\text { 輪場がないからた }\end{array}$ & 0.48 & 0.25 \\
\hline $\begin{array}{l}\text { 駐輪場が無料ならば違法駐輪 } \\
\text { は㳚少する }\end{array}$ & 0.43 & 0.14 \\
\hline 固有值 & 2.40 & 1.24 \\
\hline 寄与率 & $34.3 \%$ & $17.7 \%$ \\
\hline 累積寄与率 & $34.3 \%$ & $52.0 \%$ \\
\hline
\end{tabular}


れている。（以下本文中に用いる「マナ一意識」・「ル ール遵守」は、本章で定義した通りとする。）

主成分 $1 、 2$ を軸とし主成分得点を表したのが図 7 である。図中の楕円は各分類の確率集中棈円である。

この結果より「違法駐輪する A 類」はルール遵守を 行わない傾向にあり、反対に「違法駐輪しない B 類」 はマナー意識が高く、一方でハード整備に対する要 求は低いことがわかる。また「違法駐輪する B 類」と 「違法駐輪しない A 類」において、違法駐輪に対する 考え方について大きな差は見られない。

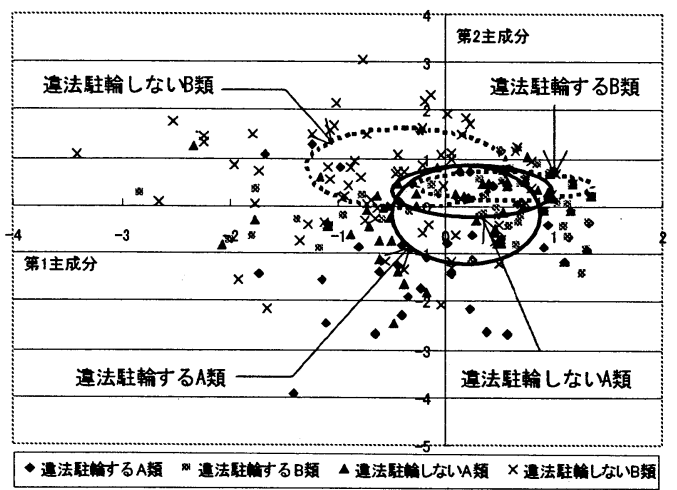

図 7. 違法駐輪に対する考えに関する主成分分析

\section{（2）違法駐輪行為抑制に関わる要因}

図 5 の主成分分析の結果より、「違法駐輪する B」 類は他人への迷惑に対する意識の強さであるマナー 意識が高い傾向にあるといえる。つまり違法駐輪す る事の善悪の判断ができているということになる。 しかし実際は違法駐輪行為を行っている。そこで違 法駐輪をしないという行動に至るには、マナー意識 が高いことは違法駐輪行為抑制のためには必要条件 ではあるが十分条件ではないことが考えられる。よ って違法駐輪行為抑制のためには、マナ一意識と共 に、他の要因が必要になると考えられる。この違法 駐輪行為抑制に関わる他の要因を検討し、これらの 要因がどのような経験により形成されているかを検 討する。

\section{(3) 違法駐輪行為抑制に関わる要因の抽出}

違法駐輪に対する考え方の中でも個人の意識に関 する項目について、各意識分類の評価値の平均を図 8 に示す。この結果より、「違法駐輪しない B 類」に 特徴的に表れているのは「他人が違法駐輪している とついつい自分も違法駐輪してしまう」、「少しの時 間駐輪するために駐輪場を利用するのは面倒だ」の 項目である。これらの項目に対し「違法駐輪しない
$\mathrm{B}$ 類」は評価値の平均が低く、面倒であっても違法駐 輪することは止めようという意識が衝いていること がわかる。よって今回のアンケート結果よりわかる 違法駐輪抑制に関わる要因は、マナー意識とルール 遵守であると考えられる。

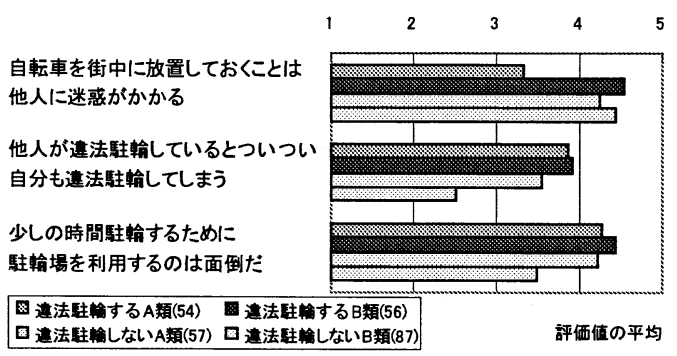

図 8. 遼法駐輪に対する考えに関する平均値

\section{5. 違法駐輪に影響する過去の履歴}

\section{(1) マナー意識の形成}

まず初めに違法駐輪に対するマナー意識の形成要 因について検討する。その中でも分散分析の検定か ら有意水準 5\%で違いの見られた項目について示す (図中に P 值を記す。)。初めに個人の自転車との関 わりや利用環境の面から分析を行う。図 9 は個人が 自転車をどの程度必要と感じているかの自転車重要 度とマナ一意識の軸とした項目との関係を示してい る。この結果より、自転車を交通手段として重要で あると回答している人は、重要でないと回答してい る人に比心゙、マナー意識が高いことが分かる。高校 生の多くは自動車や自動二輪の免許を持っていない ため、自転車が交通手段として割合の多くを占めて いる。従って交通手段としての自転車を重要でない と回答する割合はアンケート対象者全体からみると 低いが、利用の必要性がマナーを意識させる要因に なっているのではないかと考えられる。

次に現在の住んでいる地域の自転車駐輪場の便利 さとマナー意識の関係について図 10 に示す。この結 果より、地域の自転車駐輪場環境が良いと回答した 人は、マナー意識が高いことが分かる。より良い利 用環境がマナー意識を高めていると考えられる。よ って、自転車利用者の利用環境を整えることは、八 ード施設の充実だけではなく、個人の意識にも㗢き かける効果走持っていると言える。

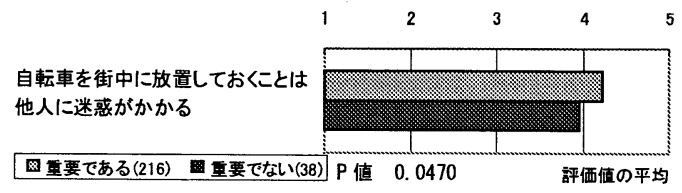

図 9. 自転車交通の重要度とマナー意識の関係 
また過去の経験の面より検討を行うと、図 11 に示 すように交通安全教室を受けた経験がある人は、違 法駐輪に対するマナー認識が高いことが分かる。交 通安全教室の中には自転車だけの交通安全教室を取 り扱うということはないが、交通全体のマナーを学 ぶという体験は単発的な体験ではあるが、マナ一意 識を高める事がいえる。 他人に迷惑がかかる

良い(53) 圆要い(201)

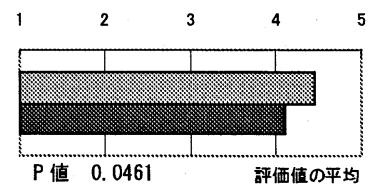

因 10. 自転車駐輪場環境とマナー意識の関係

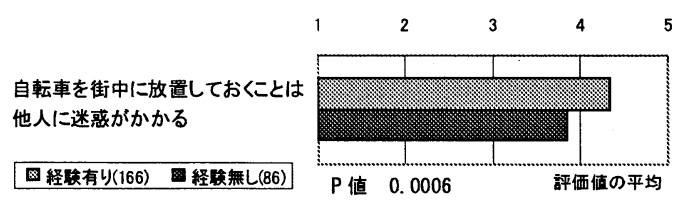

図 11. 交通安全教室の経験とマナー意識の関係

\section{(2) ルール遵守の形成}

ルールの遵守の軸とした 2 項目と過去の経験で あるへルメット着用経験の有無と、学校や家庭から 自転車の利用する範囲を限定されたことがあるかの 有無の関係 (以下「自転車利用範囲の限定」と記す) について、分散分析を行った結果有意水準 $5 \%$ で違 いの見られた項目について図 12、図 13 に示寸（図 中に $\mathrm{P}$ 值を記す。)。この結果より、ヘルメット着 用経験や自転車利用範囲の限定を経験している

\section{少しの時間駐輸するために 駐輸場を利用するのは面倒だ 因経输有以(105) 因経駼無し(146)}

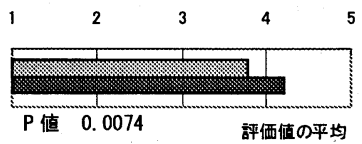

図 12.ヘルメット着用経験と違法駐輪に対する考えの関係

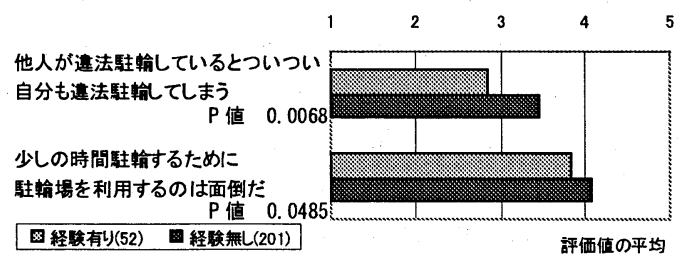

人は経験していない人よりも各項目の評価值の平均 が下がる。つまり経験者は社会的ルールを守る行動 カであるルールの遵守を起こす傾向にある。

またこれらの経験の多くは、小学生から中学生頃 までの低年齢期に経験していることが調查より分か っている。よってこれらのへルメットの着用経験や 自転車利用範囲の限定は低年齢期における一定期間 の社会の規則の遵守経験と位置付けられる。これら の経験はルールを守ることの重要性について学ぶ良 い機会であり、このような経験をした学生は「ルー ル遵守」をする傾向にあると考えられる。

\section{(3) 意識と過去の履歴}

以上の分析結果より、違法駐輪行為抑制の構成と それに影響を及ぼす要因について図 14 ・左にまとめ

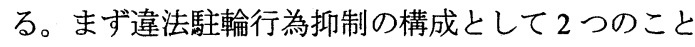
があげられる。1つ目はマナー意識であり、2つ目は ルール遵守である。これら 2 項目と図 7 と図 8 の結 果として示された各分類の特徵を図 14 ・右にまとめ る。

前者のマナー意識を高めるためには個人の自転車 との関係や、自転車利用環境の整備、また現在行わ れている交通安全教室やキャンペーン等の経験が挙 げられる。これらをまとめると良好の環境下での自 転車利用が意識を形成していると言える。また後者 のルール遵守を促すためには、ヘルメット着用経験 や自転車利用範囲の限定等の過去における自転車使 用規則の遵守体験が、形成に有効であると考えられ る。つまりマナー意識の形成には環境的要因や交通 安全教室等の現在からの教育でも、十分な効果を与 えることができると考えられる。しかしルール遵守 という行動力を形成するには、過去におけるルール 遵守体験の積み重ねが大切であり、長い年月を必要 とし形成されると考えられる。

しかしマナー意識について、形成要因と環境の変 化による意識の変化についての関係性には不明な点 が多く、更なる検討が必要である。

図 13. 自転車利用範囲の限定経験と違法駐輪に対する考えの関係

\begin{tabular}{|c|c|c|c|}
\hline & 各項目 & 過去との関係 & マナー意識 \\
\hline $\begin{array}{l}\text { マナー } \\
\text { 意識 }\end{array}$ & $\begin{array}{l}\text { ·自転車重要度 } \\
\text { ·自転車駐輪場環境 } \\
\text { · 交通安全教室 }\end{array}$ & $\begin{array}{l}\cdot \text { 自転車との関わり } \\
\text { - 自転車利用環境 } \\
\text { - 安全教室の体験 }\end{array}$ & $\begin{array}{l}\text { しないB } \\
\text { 類 }\end{array}$ \\
\hline $\begin{array}{l}\text { ルール } \\
\text { 遵守 }\end{array}$ & $\begin{array}{l}\text { ・ヘルメット着用経験 } \\
\text { - 自転車利用範囲の限定 }\end{array}$ & - 一定期間の規則の遵守経験 & $\underset{\text { レール遵守 }}{\longrightarrow}$ \\
\hline
\end{tabular}

図 14. 遑法駐輪行為抑制の構成と影響を及ぼす要因の関係 


\section{6. おわりに}

本研究において、現在の違法駐輪抑制の意識の形 成には過去の経験・環境が影響することが明らかに された。またマナー意識においては、経年変化を起 こす可能性があることが分かった。そのため、違法 駐輪を抑制するソフト施策として、意識を形成させ る対策に加えて意識を維持するための対策をとるこ とも必要である。中でもマナ一意識の維持のために 交通安全教室等を位置付けることは重要であると言 える。ただし、マナ一意識に対する経年変化につい ては、今後より十分な調査・分析を必要とする。

今後の課題として、より長い期間の意識の経年変 化を分析すること、また「違法駐輪する B 類」と「違 法駐輪しない A 類の間には明確な違いを得ること ができなかったため、意識分類の方法をより明確化 させることが必要である。そしてマナ一意識とルー ル遵守の生成要因について更なる調査・分析を行う ことが望ましい。
【参考文献】

1) 矢野伸裕・森健二 : 「自転車利用者のための交通安全教室」交 通工学 Vol.33,No.5, pp.26-30,1998

2）富原隆之・古池弘隆：「高校生の自転車交通に関する意識研究」 土木計画学研究・講演集 No.13,pp.121-126, 1990

3）安部宏史・栗井睦夫・辻和秀 :「岡山市都市部における放置自 転車の実態と駐輪意識」第 21 回交通工学研究発表会論文報 告集 2001 年 10 月 pp.9-12

4）内田武史・細見昭・黒川洸：「違法駐輸に関する意識を考慮し た自転車利用者の駐輪場選択行動特性」土木計画学研究・論 文集 Vol.19, No.3, pp.409-414,2002

5）坂口久和・吉本礼遵・吉岡倉男 - 岩崎義一 : 「大阪府の駅周辺 における放置自転車防止に関わる条例と地域的取り組みとの 相互関倸のあり方に関する研究」土木学会第 55 回年次学術講 演会 No.47,1993

6) 藤井聡・小烟篤史・北村隆一：「自転車放置者への説得的コミ ユニケーション: 社会的ジレンマ解消のための心理的方略」 土木計画学研究・論文集 Vol.19, No.3, pp.439-445,2002

\section{個人の自転車利用履歴が違法駐輪に及ぼす影響に関する研究*}

山下晴美**、古池弘隆***、森本章倫****

わが国における放置自転車問題は深刻化している。そこで今後の取り組みとして個人が自転車を放置し ないという意識を持たせる事も重要であると考えられる。よって本研究では、アンケート対象者を自転車 利用頻度の高い高校生とし、自転車放置行為を抑制する意識が、成長過程においてどのように形成されて いるかについて検討を行う。結果として二つの意識の形成が重要であると分かった。マナ一意識を持たせ ることとルールの遵守の心を持たせることである。特にルールの遵守のためには自転車利用範囲の限定経 験や自転車利用時にヘルメットの着用経験をすることが重要であることが分かった。これらの経験が有る 人は違法駐輪しない傾向にある。

\section{A Study on the Effect of Past Experience of Bicycle Usage on Illegal Parking*}

By Harumi YAMASHITA**, Hirotaka KOIKE ***and Akinori MORIMOTO****

Abandoned or illegally parked bicycles are very serious problems in many places. One of the important countermeasures to deal with this problem is to cultivate consciousness not to park illegally. In this study, we conducted a questionnaire survey to high school students who frequently use bicycle, and tried to find factors that make them refrain from illegal parking. Two factors are found to be relevant, namely, a good manner and a law-abiding mind. Especially, in order to increase law-abiding mind, it is important to have an experience of enforced rules such as wearing bicycle helmet or restricting the range of commuting by bicycle, as well as the traffic safety education in elementary and secondary schools. Those who have these experiences in their childhood are less likely to commit illegal parking when they grow up. 